ESJ Social Sciences

\title{
The Impact of Foreign Direct Investment on the Economic Growth of South Caucasus Countries
}

\author{
Lela Scholer-Iordanashvili, PhD Student
}

Business Administration, Grigol Robakidze University, Georgia

Doi:10.19044/esj.2021.v17n35p38

Submitted: 27 May 2021

Accepted: 12 October 2021

Published: 31 October 2021
Copyright 2021 Author(s)

Under Creative Commons BY-NC-ND

4.0 OPEN ACCESS

Cite As:

Scholer-Iordanashvili L. (2021). The Impact of Foreign Direct Investment on the Economic Growth of South Caucasus Countries. European Scientific Journal, ESJ, 17 (35), 38.

https://doi.org/10.19044/esj.2021.v17n35p38

\begin{abstract}
This paper focuses on the effects of foreign direct investment inflows on the economic growth in a panel of three South Caucasus countries using data from 1996-2019 periods. In this study, we applied the following control variables; trade openness, investment, real exchange rate, and population growth. Classical linear regression model was employed in this paper. Ordinary least squares methods are used for estimation. Empirical results revealed that there is no significant effect of FDI inflows on economic growth. The results show that inward FDI stock-to-GDP ratio and real GDP growth rate are positively correlated.
\end{abstract}

Keywords: Foreign direct investment, reforms, technologies, economic growth, GDP growth

\section{Introduction}

The growth and development of a country's economy depend on many factors, and one of these important growth factors is investment. Today, many countries compete for attraction of foreign investments. Competition is expressed in offering of business environment suitable for investments.

In Georgia, inflow of foreign direct investments (FDI) began from 1996. During the last 24 years (1996-2020), Georgia attracted investments in total amount of 16.5 billion USD. This makes up an average of 823 million USD annually. According to the data of the last 24 years, the largest investor country in Georgia is Azerbaijan with a total of 2.2 billion USD invested. 
Second on the list is the United Kingdom (Great Britain) with a total of 2 billion USD. On the third place are Netherlands with a total of 1.6 billion USD investments. Azerbaijan and British investments (mainly British Petroleum) are basically connected to oil and gas pipelines lied through Georgia, which connect Azerbaijan oil and gas to Turkey ${ }^{1}$.

According to the last data of 2020, the largest FDI in Georgia came from United Kingdom with 307 million USD. On the second place is Netherland with 172 million USD, and on the third place is Turkey with 108 million USD. FDI in Georgia amounted to 616.9 million USD in 2020 (preliminary data), and down to 52.9 percent from the same period of the previous year'.

Which sectors of Georgian economy attract FDI most of all? If we look at the statistics of the last 20 years (schedule 5), we observed that most investments were made in the transport and communication sector amounting to 3.2 billion USD. This sector occupies first place because of investments made in pipelines transport. On the second place is power energy with 1.8 billion USD. Investments made in the power energy sector are basically connected to construction of hydro power stations. From 1997-2019, lowest FDI were made in agricultural sector as only 134 million USD was realized (averagely 6.7 USD annually).

During the last decade, foreign direct investments have played certain role in the development of Georgian economy and assisted to move to the new stage of development. Nonetheless, investments flows in Georgia are less stable from the stand point of fragment, production, and export support. Based on Investment Development Path, research shows that Georgia is on the second level of its development. This means that inflow investments are prevailing on outflow investments, and the country is still progressing based on non modern technology-based economy (Sikharulidze, 2018).

Azerbaijan is one of the Caucasus countries rich in oil reserves, which also attract FDI. According to the data of State Statistical Committee of the Republic of Azerbaijan, after gaining of independence, Azerbaijan faced inflow of large volumes of FDI. If 2001 volume of FDI made up 1.092 million USD according to the data of 2020, this volume exceeded 12000 million USD. If we examine distribution of FDI by sector, we will see that the FDI is basically focused on oil sector. However, the oil sector is not the only motivating factor for inward FDI. The country has also developed attractive business environment provided by government programs (Frayne, 2012).

\footnotetext{
${ }^{1}$ National Statistics of Georgia https://www.geostat.ge/en/modules/categories/191/foreigndirect-investments

${ }^{22}$ National Statistics of Georgia https://www.geostat.ge/en/modules/categories/191/foreigndirect-investments
} 
Figure 1below shows the volume of FDI inflow in Azerbaijan for the last decades.

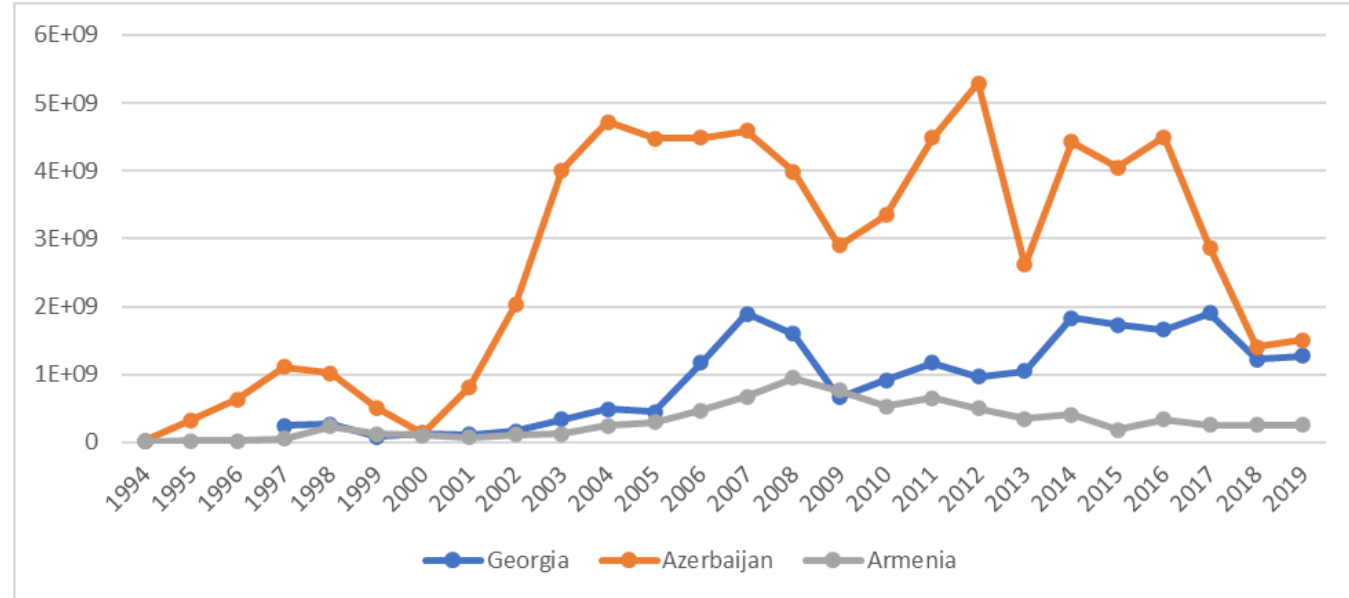

Figure 1. Foreign Direct Investment in South Caucasus Countries ${ }^{3}$

As in Georgia and Azerbaijan, FDI has been inflowing in Armenia since the 1990s. A year after the restoration of Armenia's independence, the stock of funds invested in the Armenian economy by foreign partners amounted to 2 million USD. This situation can be connected to the high instability of the market in the first half of $1990^{\text {th }}$ (among them high investment risk), caused by systemic transformation, economic crisis, and armed conflict in Nagorno-Karabakh (from 1988). From 1994, the Government implemented many important reforms which are connected to the inflow of direct foreign investments. This resulted in the growth of the economy, and then membership in the World Trade Organization (January 2003). First significant declining of FDI was observed in 1998 (KaczmarekKhubnaia, 2017). Important inward stock of FDI in Armenia is connected to the operations of the following companies: Greek company (GTE) has invested in telecommunication sector, Pernod Ricard has bought Yerevan Cognac Company (YBC), and Furtono acquired Armenian Diamond Company (Bartlett, 2000). In 2014, the FDI net inward was made up of 182.3 million USD, which makes up 4.4 percent of GDP. Moreover, the largest part of investments comes from Russian investors who made these investments in energetic sector. This fact made up almost the half of foreign direct investments inward, and it significantly exceeds the volume of investments realized in the mining and telecommunication sectors. Inward FDI stock in Armenia is also connected to the policy implemented by the Government, which was aimed at improving the investment environment. Armenian Government has made significant changes in order to improve business

${ }^{3}$ The World Bank Data: https://data.worldbank.org/country 
environment by amending the FDI law to improve investor protection. According to the UNCTAD's World Investment Report (2020), in 2018, inward foreign investments in Armenia made up to 254 million USD which is unchanged from the previous year. In 2019, stock of foreign direct investments was evaluated at 5.7 billion USD. Russia, Greece, Cyprus, and Germany are four main investors. Furthermore, significant investments are also implemented by members of Armenian diaspora (almost 6 million people). Sectorial distribution of foreign direct investments in Armenian economy is as follows: energy, telecommunications, metallurgy, hotel services, and air transportation ${ }^{4}$.

From this standpoint, it would be very interesting to analyze influence of direct foreign investments on the economy of South Caucasus.

\section{Literature Review}

Policy makers and scientists argue that FDI can have an important positive effect on development of host country. FDI can be the source of technologies and know-how when integrated with local economy. FDI plays an important role in support of economic growth, improvement of technological level of the country, creation of new possibilities for employment, and availability of capital for developing countries (Loungani, 2001). Besides, there is learning advantage which foreign direct investments offer to local governments, local businesses and citizens to study new business practice, management techniques, and conceptions. Thus, this helps them in the development of local business and industries (Kumar, 2014). Furthermore, foreign direct investments help developing countries to integrate in global markets, and also make available global capital for growth of investments which causes growth of economy needed for reduction of poverty and improve standards of living (Dollar, 2002; Rutihinda, 2007).

Hanson (2001) argues that evidence of the fact that FDI have positive spillovers for the host country is somehow weak. On the basis of the analysis of micro data, Gorg (2002) concluded that spillovers from firms based on foreign capital to the local firms in most cases is negative. Lipsey (2002) has a different opinion which, after analysis of literature at the micro level, proves that there are positive effects. In addition to the result of the empirical study conducted at macro level, he concluded that there is no consistent connection between inward FDI stock and GDP growth. Besides, he argues that analysis of spillovers requires consideration of the country and industry specificity. The relationship between FDI and domestic investment in Georgia was studied by Sikharulidze (2015) for the post 1990 period. In his work, Sikharulidze

${ }^{4}$ Foreign Direct Investment (FDI) in Armenia

https://www.lloydsbanktrade.com/en/market-potential/armenia/investment 
shows crowding out of local investments in Georgia. The results of econometric analysis of the total investment model presented in this paper show the evidence of crowding out long-term effect of FDI on investment in Georgia. Dzegvelishvili (2018) conducted an empirical analysis during 19972017 for Georgia, which shows that FDI inflows into the agricultural and manufacturing sector tend to have a negative effect on growth. On the contrary, the FDI inflows in service sector have positive effect.

According to Blomstrom (2003) and Borensztein (1998), the contributions of FDI to the development are extensively recognized as filling the gap between desired investments and domestically mobilized increasing tax revenues, saving and improving managerial know-how and technology, as well as managerial skills in host countries. However, the impact of foreign direct investments on the economic growth has no immediate effect. Borenzstein (1998) argues that in order for FDI to have a positive effect over economy growth, the country shall necessarily achieve minimum threshold level of development in education, technologies, infrastructure, financial markets, and healthcare industry (Borensztein, 1998).

Indeed, FDI contributes to economic growth only when the host country has reached a developmental level capable of absorbing the advanced technology that it brings (Elboiashi, 2011). According to Klein (2001), business environment in which foreign investors are operating shall be improved for successful implementation of FDI, which will be followed by economic growth and reduction of poverty.

Empirical studies show that FDI are very crucial for economic development, and this is because they are source of capital attraction and complements domestic private investments. According to Blomström (2003) and Chen (2002), foreign direct investments provide to the growth of total factor productivity and growth of incomes in the host economy more than domestic investments can do.

Xiaoying Li (2004) have revealed direct connection between FDI and economic growth. During analysis of this connection, the level of local human capital development and technological achievements was also taken into account. Positive direct effect is confirmed for developed and developing countries. Nair-Reichert (2001) has studied causal connection between foreign investments and economic growth in dynamic panel, which covers 24 developing countries. Thus, the work controlling variables include investments, inflation, openness quality, and human capital. On average, foreign direct investments have a positive impact on growth, and higher quality of openness strengthens positive aspects of FDI (Adhikary, 2011).

Therefore, it shall be noted that empirical literature does not give consensus on connection between foreign direct investments and the whole economy. Some researches reveal positive effect of foreign direct 
investments on productivity and growth of the GDP, and the others reveal negative connection or weak interaction. Besides, during empirical studies, it is important to consider such country specificity as the level of economic, technological, infrastructural, and institutional development (Adhikary, 2011). Therefore, starting from this point of view, this leads us to our hypothesis. FDI has a statistically significant impact on the economies of the South Caucasus countries.

\section{Methodology: Model Specification}

For testing the hypothesis in the model applied in research, there is an explained interaction between FDI and economic growth using cross-section regressions with 3 countries for the time period (1996-2019). The model also provides all those factors which can potentially and significantly affect growth rate of GDP. According to the theories and empirical studies, FDI-to-GDP ratio apart, economic growth is determined by factors such as gross fixed capital formation, trade liberalization or degree of openness, exchange rate, and labor force (see Table 1). The analysis was implemented using EViews 10 Software.

Table 1.

\begin{tabular}{|l|l|c|c|c|c|c|c|}
\hline \multirow{2}{*}{ Growth } & \multirow{2}{*}{ F } & FDI & GFCF & Trade & Infl & Rer & Labour \\
\cline { 3 - 8 } & + & + & + & - & + or - & + \\
\hline
\end{tabular}

In the theoretical analysis, as already mentioned, the FDI inflow increases GDP growth through modern technologies and improvements of managerial skills. Feldstein (2000) argues that FDI allows for technology transfers that cannot be achieved through financial investment and trade in goods and services. It is also important to consider the impact of control variables on economic growth. Among the driving factors of the long-term growth, the openness of the economy is widely recognized. Trade plays an important role in ensuring economic growth. Trade liberalization allows local firms to access the best technologies and management skills ( Baily, 1995; Miller, 2000). When analyzing the openness of the economy, it is important to consider the impact of the real exchange rate on economic growth. Chiefly, the exchange rate of a country plays a key role in international economic transactions. For example, an increase in exchange rate may increase the demand of domestic products and the cost of imported capital and other imported inputs. Theories and empirical studies show that population growth, labor force, and gross fixed capital formation can affect both individual sectors as well as the economy as a whole. Proponents of labor suggest that population growth allows the rural sector to play a role in fostering economic growth (Pemberton, 2002). A large number of the population provides a large 
domestic market. In addition, population growth encourages competition that includes technological advances and innovations (Tsen, 2005) (see Table 1).

Thus, the variables appearing in the equations are defined as follows (Manamba Epaphra, 2017):

Table 2. Variables Description

\begin{tabular}{|c|c|c|}
\hline Symbols & Description & Sources \\
\hline LnGrowth & Real GDP growth, annual percent. & World Bank data \\
\hline FDI-to-GDP & Inward FDI to GDP & World Bank data \\
\hline GFCF & $\begin{array}{l}\text { Gross fixed capital formation, percent } \\
\text { of GDP. GFCF is made up of } \\
\text { machinery, plant, purchases of } \\
\text { equipment, industrial buildings, } \\
\text { construction of railways, and roads. }\end{array}$ & World Bank data \\
\hline Trade & $\begin{array}{l}\text { Trade openness, measured as export } \\
\text { and import, percent of GDP. }\end{array}$ & World Bank data \\
\hline RER & Real exchange rate. & World Bank data \\
\hline Infl & $\begin{array}{l}\text { Inflation rate, measured as the growth } \\
\text { rate of consumer price index as a proxy } \\
\text { of macroeconomic stability. }\end{array}$ & World Bank data \\
\hline Labour & Population growth, annual percent. & World Bank data \\
\hline GDPin & Initial GDP. & World Bank data \\
\hline GE & $\begin{array}{lcr}\text { General } & \text { government } & \text { final } \\
\text { consumption expenditure }(\% \text { of GDP). }\end{array}$ & World Bank data \\
\hline
\end{tabular}

The ordinary least squares method (OLS) is used for estimation. OLS is simple and widely used in empirical work. We calculated the impact of overall FDI inflows on economic growth based on the following equation (Borensztein, 1998; Carkovic, 2005; Alfaro, 2003):

$$
\begin{gathered}
\text { lnGrowth }=\beta_{0}+\beta_{1} \operatorname{lnFDI}_{t}+\beta_{2} \text { lnGFCF }_{t}+\beta_{3} \text { trade }_{t}+ \\
\beta_{4} \text { RER }_{t}+\beta_{5} \text { Lnlabour }_{t}+\beta_{6} G D \text { Pin }_{t}+\beta_{7} G E_{7}+\varepsilon_{t}(1)
\end{gathered}
$$

Where,

$$
\begin{gathered}
\beta_{0}, \beta_{1} \ldots \beta_{n}-\text { parameters to be estimated, } \\
\mathrm{t}-1, \ldots, \mathrm{T}-\text { the period of time, years, } \\
\varepsilon_{t}-\text { white noise error term. }
\end{gathered}
$$

The data for the variables which are included in the estimation models (Real GDP growth, real exchange rate, trade as a percent of GDP, labour) are obtained from World Bank and World Development Indicators ${ }^{5}$. Growth is the dependent variable and is defined as the annual growth rate of real GDP per capital. FDI-to-GDP represents the annual inward FDI inflows as a share of

${ }^{5}$ The world bank indicators: https://data.worldbank.org/country 
GDP, and it is the primary variable of interest through which we test the contribution of FDI for the host countries in our sample. According to the theory, we consider the variable gross capital formation which is implied to capture the impact of domestic investment on economic growth. Gross capital formation as a share of GDP is used as a proxy. The model also considers a measure of trade openness calculated as a ratio of exports and imports to GDP (Trade). We also control the effect of foreign exchange, population growth, and annual percent. Furthermore, we are interested in $\beta_{1}$ coefficient for testing the hypothesis formulated in the study.

\section{Estimation Techniques}

The ordinary least squares method is applied for estimation. The ordinary least squares method is widely used in empirical work. The cointegration methodology is employed to determine the long run relationships among the variables.

Table 3 provides correlation between the ratio of GDP and real exchange rate. Additionally, the degree of liberalization and gross fixed capital formation is positive. GDP growth negatively correlates with population growth rate.

Table 3. Estimates of Correlation Coefficient ${ }^{6}$

\begin{tabular}{|c|c|c|c|c|c|c|}
\hline & Growth & $\begin{array}{c}\text { FDI-to- } \\
\text { GDP }\end{array}$ & GFCF & Trade & $\begin{array}{c}\text { Exchange } \\
\text { rate }\end{array}$ & Labour \\
\hline Growth & 1,00 & & & & & \\
\hline FDI-to-GDP & 0,25 & 1,00 & & & & \\
\hline GFCF & 0,23 & 0,68 & 1,00 & & & \\
\hline Trade & 0,10 & 0,39 & 0,17 & 1,00 & & \\
\hline Exchange rate & 0,08 & $-0,49$ & $-0,37$ & $-0,31$ & 1,00 & \\
\hline Labour & $-0,16$ & 0,18 & 0,09 & 0,21 & $-0,22$ & 1,00 \\
\hline
\end{tabular}

\section{Empirical Results}

The goal of the empirical analysis is to analyze whether FDI have effects on a country's economic growth. Following Borensztein (1998), Carkovic (2005) and Alfaro (2003), we look at the direct effect of the FDI on economic growth using cross-section regressions with 3 countries for the time period (1996-2019). We calculated the impact of overall FDI inflows on economic growth based on equation (1) using Stata 14 software. 
Table 4. Growth and Total FDI ${ }^{7}$ Dependent Variable - Real GDP Growth Rate

\begin{tabular}{|c|c|c|c|c|c|c|}
\hline Independent variables & 1 & 2 & 3 & 4 & 5 & 6 \\
\hline InFDI-to-GDP & $\begin{array}{c}0.343192 \\
(0.161337) \\
\end{array}$ & $\begin{array}{c}0.240433 \\
(0.221907) \\
\end{array}$ & $\begin{array}{c}0.231459 \\
(0.242043) \\
\end{array}$ & $\begin{array}{c}0.274173 \\
(0.239067) \\
\end{array}$ & $\begin{array}{c}0.408986 \\
(0.251905) \\
\end{array}$ & $\begin{array}{c}0.418962 \\
(0.256624) \\
\end{array}$ \\
\hline $\operatorname{lnGFCF}$ & & $\begin{array}{c}0.435151 \\
(0.642200)\end{array}$ & $\begin{array}{c}0.444208 \\
(0.653868)\end{array}$ & $\begin{array}{c}0.411121 \\
(0.642913)\end{array}$ & $\begin{array}{c}0.345857 \\
(0.641536)\end{array}$ & $\begin{array}{c}0.2028 \\
(0.634227)\end{array}$ \\
\hline InTrade & & & $\begin{array}{c}0.073965 \\
(0.763400)\end{array}$ & $\begin{array}{c}0.279859 \\
(0.758938)\end{array}$ & $\begin{array}{c}0.45911 \\
(0.761891)\end{array}$ & $\begin{array}{c}1.092235 \\
(0.807668)\end{array}$ \\
\hline InLabour & & & & $\begin{array}{c}-0.237651 \\
(0.131755)\end{array}$ & $\begin{array}{l}-0.200232 \\
(0.134279)\end{array}$ & $\begin{array}{l}-0.396528 \\
(0.269834)\end{array}$ \\
\hline InExchange rate & & & & & $\begin{array}{c}0.079442 \\
(0.054914)\end{array}$ & $\begin{array}{c}0.119808 \\
(0.132106) \\
\end{array}$ \\
\hline Inflation & & & & & $\begin{array}{r}-0.016429 \\
(0.023123) \\
\end{array}$ & $\begin{array}{c}-0.03076 \\
(0.023648) \\
\end{array}$ \\
\hline GE & & & & & & $\begin{array}{c}-0.134604 \\
(0.06668)\end{array}$ \\
\hline GDPin & & & & & & $\begin{array}{c}4.7884 \\
(9.4334) \\
\end{array}$ \\
\hline $\mathbf{C}$ & $\begin{array}{c}0.941159 \\
(0.339085)\end{array}$ & $\begin{array}{c}-0.251202 \\
(1.792338) \\
\end{array}$ & $\begin{array}{c}-0.587691 \\
(3.914515)\end{array}$ & $\begin{array}{c}-1.480832 \\
(3.879101) \\
\end{array}$ & $\begin{array}{c}-2.413697 \\
(3.925235)\end{array}$ & $\begin{array}{l}-3.764071 \\
(4.376452) \\
\end{array}$ \\
\hline Observations & 68 & 68 & 68 & 68 & 68 & 68 \\
\hline F-statistic & 4.58 & 2.47 & 1.62 & 2.07 & 2.87 & 2.82 \\
\hline $\mathrm{R}^{2}$ & 0.06 & 0.07 & 0.07 & 0.11 & 0.16 & 0.545 \\
\hline
\end{tabular}

Consequently, the main purpose of this analysis is to examine the impact of FDI on a host country's growth. Table 4 summarizes the results of fixed effects panel estimation. The regressions shows FDI have a positive and insignificant effect on growth (Column 1). As it can be seen from the table, FDI does not maintain their significant positive effect after controlling for gross fixed capital formation (Column 2), trade openness (Column 3), and exchange rate and population growth variables (Columns 4-5). Moreover, the coefficient on FDI is rather stable and ranges from 0.34 in the case when there are no control variables to 0.4 in the cases when we control all variables. In fact, GDP real growth did not respond to an increase in FDI inflow-to-GDP ratio over the 1996-2019 periods. This is the case when the impact of FDI is neutral, which is consistent with the opinion of scholars who have revealed a weak or negative interaction between FDI and GDP growth. F-statistic is significant at 1 percent, rejecting the null hypothesis that all the regressors have coefficients not different from zero. This suggests that the model estimated has good overall explanatory power. R-squared, which measures the goodness of fit of the variables, is not sufficiently large. This suggests that about 16 percent of the variations in GDP is jointly explained by the regressors during the 1996-2019 period (Column 5).

${ }^{7}$ Source: Authors' Calculations. 
The fifth column of the table shows that FDI have a positive but not significant impact on economic growth. In addition, investments and trade openness have a positive impact on economic growth. Nonetheless, their impact is not statistically significant. The coefficient for the labor force is significantly different from zero at the 1 percent level, suggesting that a 1 percent increase in labor force may reduce real GDP growth by 0.2 percent ceteris paribus.

Table 4 shows that inflation has a negative impact on economic growth. This result is not surprising since the uncertainty about price change affects growth through distortions in the allocation of resources, and through discouraging the overall accumulation of physical capital. The impact of inflation may hinder the formation of savings and investment, and this will ultimately leads to low GDP growth rates. The real exchange rate has a negligible and non-significant effect on the real GDP growth during the sample period.

In the sixth column, two more variables are added: initial GDP and government expenditure. With addition of these variables, $\mathrm{R}$-squared became 0.54 which is not small, and about 54 percent of the variations in GDP is jointly explained by the regressors.In addition to these variables, FDI still has a positive impact on economic growth.

\section{Conclusion}

Since the collapse of the Soviet Union, most post-Soviet countries, including the Caucasus countries, have faced severe economic challenges, both in terms of the depth and duration of the economic crisis. Economic recovery in all three countries has been under way since 1996. It was during this period that the inflow of FDI began, and this has made some contribution to overcoming the economic crisis of these countries. Hence, the interest of our research is the impact of FDI on the economic growth of these countries. This paper is confined to FDI inflows and economic growth in South Caucasus countries during the 1996-2019 periods. During this period, the government of these countries attracted a substantial amount of FDI through various incentives policy. The goal of this study is to investigate the impact of FDI inflows on real GDP growth, FDI-to-GDP ratio, and real GDP growth apart. The control variables included in the models are gross fixed capita formation, population growth rate (labour), real exchange rate, and the ratio of imports plus export-to-GDP (degree of trade liberalization or openness). Time series data spanning from 1996 to 2019 are used for estimation and analysis. Data are obtained from World Bank, World Development Indicators, UNCTAD, and National Statistics Office of Georgia.

The empirical findings suggest that there is no significant effect between FDI and real GDP growth. However, the relationship between FDI 
and real GDP growth is positive. It is also revealed that the correlation between FDI and real economic growth is positive but not strong. The positive effect of FDI on overall economic growth implies that a recent improvement in the economy of South Caucasus countries is due to improvement in the growth of non-agricultural sectors. The results of the study are consistent with the opinion of scholars that the impact of FDI on economic growth is not unambiguous.

Thus, productivity is vital to sustaining high economic growth. Longterm economic growth models point to the main challenges for the growth of the economy, given the limited opportunities for population growth and a sharp increase in domestic savings. One of the main factors for increasing productivity is the attraction of efficiency-seeking FDI, which in turn boost integration into global markets due to expert-oriented activities.

According to our research, although FDI have a positive impact on economic growth, there are still unanswered questions. In this regard, the research will take into account the sectors of the economy such as industry, services and agriculture, as well as the characteristics of the country.

\section{References:}

1. Adhikary, B. (2011). FDI, Trade Openness, Capital Formation, and Economic Growth in Bangladesh: A Linkage Analysis. . International Journal of Business and Management, , pp. 16-28.

2. Alfaro, L. A. C. O. (2003). FDI and Economic Growth: The Role of Local Financial Markets. Journal of International Economics.

3. Baily, M. A. (1995). Efficiency in Manufacturing and the Need fo Global Competition. Brookings Papers on Economic Activity: Microeconomics, , pp. 307-358.

4. Bartlett, D. L. (2000). Stabilization Policy in Post-Soviet Armenia. Post-Soviet Geography and Economics, , 41(1), 30-47.

5. Blomström, M. A. (2003). The Economics of Foreign Direct Investmen Incentives. NBER Working Papers 9489, National Bureau of Economic Research,. Cambridge. Retrieved from econpapers.repec.org/RePEc:hhs:eijswp:0168

6. Blomstrom, M. A. (2003). The Economics of Foreign Direct Investment Incentives. Cambridge.: NBER Working Papers 9489, National Bureau of Economic Research. Retrieved from https://doi.org/10.3386/w9489

7. Borensztein, E. D. (1998). How Does Foreign Direct Investment Affect Economic Growth? Journal of International Economics, pp. 115-135. Retrieved from https://doi.org/10.1016/S00221996(97)00033-0 
8. Carkovic, M. A. (2005). Does Foreign Direct Investment Accelerate Economic Growth? Washington, DC: Institute for International Economics and Center for Global Development.

9. Chen, Y. A. (2002). Foreign Direct Investment and Manufacturing Productivity in China. CEPII Research Project on the Competitiveness of China's Economy.

10. Dollar, D. A. (2002). Growth Is Good for the Poor. Journal of Economic Growth, pp. 195-225. Retrieved from https://doi.org/10.1023/A:1020139631000

11. Dzegvelishvili, L. (2018). The impact of Foreign direct investment on the economy of Georgia. Journal of Young Researchers.

12. Elboiashi, H. A. (2011). The Effect of FDI and Other Foreign Capital Inflows on Growth and Investment in Developing Economies. Glasgow.

13. Feldstein, M. (2000). Aspects of Global Economic Integration: Outlook for the Future. NBER Working Paper No. 7899, National Bureau of Economic Research.

14. Frayne, T. (2012). Energy Sector FDI in Azerbaijan: An Example of Good Governance? E-International relations. Retrieved from https://www.e-ir.info/2012/08/05/energy-sector-fdi-in-azerbaijan-anexample-of-good-governance/

15. Gorg, H. A. (2002). Much Ado About Nothing? Do Domestic Firms Really Benefit from Foreign Direct Investment?". Research Paper 2001/37, Globalisation and Labour Markets Programme, at Leverhulme Centre for Research on Globalisation and Economic Policy.

16. Hanson, G. H. (2001). Should Countries Promote Foreign Direct Investment?". G-24 Discussion, New York: United Nations. , Paper No. 9.

17. Kaczmarek-Khubnaia, J. (2017). Foreign direct investment in Armenia. Journal of Geography, Politics and Society, pp. 48-49.

18. Klein, M. A. (2001). Foreign Direct Investment and Poverty Reduction. Policy Research Working Paper, World Bank eLibrary. Retrieved from https://doi.org/10.1596/1813-9450-2613

19. Kumar, M. (2014). FDI and Indian Economic Growth Factors-An Empirical Analysis. International Journal of Management and Commerce Innovations, pp. 7-15.

20. Lipsey, R. E. (2002). Home and Host Country Effects of FDI. NBER Working Paper 9293.

21. Loungani, P. A. (2001). How Beneficial Is FDI for Developing Countries? Finance \& Development: A Quarterly Magazine of IMF. Retrieved from 
http://www.imf.org/external/pubs/ft/fandd/2001/06/loungani.htm

22. Manamba Epaphra, A. H. (2017). Analysis of Foreign Direct Investment, Agricultural Sector and Economic Growth in Tanzania. Scientific Research Publishing, pp. 111-140.

23. Miller, S. A. (2000). The Effects of Openness, Trade Orientation, and Human Capital on Total Factor Productivity. Journal of Development Economics, pp. 399-423.

24. Nair-Reichert, U. A. (2001). Causality Tests for Cross-Country Panels: a New Look at FDI and Economic Growth in Developing Countries. Oxford Bulletin of Economics and Statistics, , pp. 153-171.

25. Pemberton, C. (2002). A Population Growth Theory of Rural Development. In Rural Development Challenges in the Next Century. Proceedings of the International Conference of ALACEA-The Latin American and Caribbean Association of Agricultural Economists, edited by Carlisle A. Pemberton, , (pp. pp. 214-227). Trinidad and Tobago.

26. Rutihinda, C. (2007). Impact of Globalization on Small and Medium Size Firms in Tanzania. ABR \& TLC Conference Proceedings, , . Hawaii, USA.

27. Sikharulidze, D. T. T. (2015). The impact of FDI on domestic investment (in case of Georgia). Social and Economic Revue, pp 3540.

28. Sikharulidze, D. C. (2018). OLI paradigm and investment position of Georgia. Globalization\&Business, pp. 71-78.

29. Tsen, W. A. (2005). The Relationship between Population and Economic Growth in Asian Economies. ASEAN Economic Bulletin, pp. 314-330.

30. Xiaoying Li, X. L. (2004). Foreign Direct Investment and Economic Growth: An Increasingly Endogenous Relationship. World Development, pp. Vol. 33, No. 3, pp. 393-407. 